Revista de Derecho Político, núm. 25, 1987, págs. 295-329

\title{
ELECCIONES LEGISLATIVAS EN PORTUGAL
}

\author{
PILAR MELLADO PRADO
}

El domingo 19 de julio, el pueblo portugués acudió a las urnas para elegir los 250 diputados de la Asamblea de la República y los 24 que le corresponden en el Parlamento Europeo.

Por primera vez desde 1974, el centro-derecha se alzaba con el triunfo al conseguir el Partido Socialdemócrata de Cavaco Silva la mayoría absoluta de la Asamblea con 148 diputados $(50,22$ por 100 de los votos emitidos). Con la victoria del PSD se cierra en Portugal la transición política y se vislumbra una reforma constitucional que permitirá realizar algunos importantes ajustes institucionales.

Por otra parte, aunque los socialistas suben un 2 por 100 en relación a las elecciones de 1985, se han quedado muy lejos de los resultados que obtuvieron en 1983, cuando Mario Soares era Secretario General del PSP. Los comunistas (CDU) pierden siete escaños y el Partido Renovador Democrático de Ramalho Eanes ha sufrido un serio revés al perder 38 escaños.

A continuación reproducimos los resultados de estas elecciones legislativas y de las del Parlamento Europeo.

\section{ELECCIONES LEGISLATIVAS 1987}

\begin{tabular}{lllll}
\hline Inscritos & - & 7.930 .668 & \\
Votantes & - & 5.676 .358 & - & $71,57 \%$ \\
Blancos & - & 50.135 & - & $0,88 \%$ \\
Nulos & -73.533 & - & $1,29 \%$
\end{tabular}




$\begin{array}{rrrrrrr}\text { PSD- } & 2.850 .784 & - & 50,22 \% & - & 148 \text { diputados } \\ \text { PS- } & 1.262 .506 & - & 22,24 \% & - & 60 \text { diputados } \\ \text { CDU- } & 689.137 & - & 12,14 \% & - & 31 \text { diputados } \\ \text { PRD- } & 278.561 & - & 4,91 \% & - & 7 \text { diputados } \\ \text { CDS- } & 251.987 & - & 4,44 \% & - & 4 \text { diputados }\end{array}$

PARLAMENTO EUROPEO

$\begin{array}{lrrrr}\text { Inscritos } & - & 7.787 .603 & & \\ \text { Votantes } & - & 5.639 .650 & - & 72,42 \% \\ \text { Blancos } & - & 68.475 & - & 1,21 \% \\ \text { Nulos } & - & 74.240 & - & 1,32 \%\end{array}$

\begin{tabular}{|c|c|c|c|c|c|}
\hline PSD & - & 2.111 .828 & - & $37,45 \%$ & - $\quad 10$ diputados \\
\hline PS & - & 1.267 .672 & & $22,48 \%$ & 6 diputados \\
\hline CDS & - & 868.718 & - & $15,40 \%$ & 4 diputados \\
\hline DU & - & 648.700 & - & $11,50 \%$ & 3 diputados \\
\hline PRD & - & 250.150 & & $4,44 \%$ & 1 diputado \\
\hline
\end{tabular}

Fuente: Embajada de Portugal en Madrid.

INDICE DE SIGLAS

PSD = Partido Socialdemócrata

PS = Partido Socialista

CDS $=$ Centro Democrático Social

CDU $=$ Coalición Democrática Unitaria

PRD = Partido Renovador Democrático 